\title{
TOŻSAMOŚĆ MIASTA W KONTEKŚCIE PRZEMIAN POLITYCZNYCH, EKONOMICZNYCH I SPOLECZNYCH WE WSPÓŁCZESNEJ POLSCE. PRZYPADEK KIELC
}

Opracowanie powstało $\mathrm{w}$ ramach badań statutowych prowadzonych przez prof. dr hab. Elżbietę Firlit pt. „Tożsamości kulturowe w Europie - ciągłość i zmiana”. Celem autorki jest ocena wpływu współczesnych przemian politycznych, ekonomicznych i społecznych na tożsamość miasta oraz scharakteryzowanie tożsamości Kielc. Opracowanie składa się z trzech części: zdefiniowania różnych podejść do pojęcia tożsamości; analizy relacji między współczesnymi przemianami, takimi jak transformacja systemowa w Polsce, globalizacja, metropolizacja, integracja europejska, a tożsamością miasta oraz charakterystyki tożsamości Kielc.

\section{Tożsamość miasta w ujęciu teoretycznym}

Tożsamość miasta jest bardzo specyficzną formą tożsamości wywodzoną z pojęć takich jak tożsamość społeczna (zbiorowa), tożsamość kulturowa, a także tożsamość terytorialna czy regionalna. Pojęcie tożsamości miasta jest również silnie związane z koncepcją tożsamości miejsca i przestrzeni oraz z koncepcjami powstałymi na gruncie badań nad zarządzaniem organizacjami i ich tożsamością.

W literaturze przedmiotu tożsamość społeczna, zwana również zbiorową ${ }^{1}$, jest określana jako „zwielokrotniona tożsamość indywidualna oparta na wspólnych lub zbliżonych dla wszystkich lub większości aktorów systemach wartości, norm, obyczajów, zwyczajów, języka, gospodarki czy określonego terytorium”2. W przytoczonym cytacie tożsamość indywidualną autorka rozumie jako „zbiór wyobrażeń, sądów i przekonań, które aktor społeczny konstruuje wobec samego siebie”3.

1 A. Śliz, M. Szczepański, Tożsamość jednostkowa i zbiorowa $w$ procesie metropolizacji, w: Stałość i zmienność tożsamości, Wydawnictwo KUL, Lublin 2010, s. 276.

2 Ibidem, s. 277.

3 Z. Bokszański, Tożsamość, interakcja, grupa. Tożsamość jednostki w perspektywie teorii socjologicznej, Wydawnictwo UŁ, Łódź 1989, s. 12. 
Jednym z rodzajów tożsamości zbiorowej jest tożsamość kulturowa. Jej istotą jest historycznie uwarunkowany, kulturowy sposób zachowania przez daną zbiorowość ludzką istnienia i ciągłości gatunku. Definiuje się ją jako względnie trwałą identyfikację pewnej grupy ludzi i pojedynczych jej członków z określonym układem kulturowym tworzonym przez zespół idei, przekonań, poglądów, z konkretnymi zwyczajami i obyczajami. Identyfikacja ma na celu umacnianie wewnętrznej jedności grupy".

Szczególnym przypadkiem tożsamości zarazem społecznej i kulturowej jest tożsamość regionalna. Zasadza się ona na tradycji regionalnej odnoszonej do wyraźnie zdefiniowanego terytorium, regionu, jego charakterystycznych cech społecznych, kulturowych, gospodarczych czy topograficznych ${ }^{5}$. Tożsamość regionalną można uznać równocześnie za tożsamość tradycyjną. Odnosi się ona przede wszystkim do więzi międzyludzkich i jest związana z przywiązaniem do danego miejsca ${ }^{6}$. Do tych samych wartości odwołuje się tożsamość miejsca, którą przeciwstawia się tożsamości przestrzeni ${ }^{7}$. Zgodnie z tym rozróżnieniem miejsce jest wydzielonym fragmentem przestrzeni, który jest oswojony i bezpieczny, a elementy tworzące jego strukturę zostały przez człowieka naznaczone i rozpoznane. Przestrzeń natomiast symbolizuje wolność, przepływy, a równocześnie coś nieoswojonego. Ten podział jest nieodłącznie związany z procesami metropolizacji, które podzieliły społeczeństwo na związane z przestrzenią elity metropolitarne oraz związanych z miejscem ludzi peryferii ${ }^{8}$. Ludzie peryferii przywiązani są do tradycji, historii oraz miejsca i dlatego ich tożsamość to tożsamość miejsca9. Elity metropolitarne często zmieniają miejsce pobytu i nie przywiązują się do terytorium, dlatego ich tożsamość to tożsamość przestrzeni. Z tego podziału wynika wniosek, że tożsamość miasta to tożsamość miejsca, a tożsamość metropolii to tożsamość przestrzeni ${ }^{10}$.

Drugim nurtem teoretycznym, do którego nawiązuje definicja tożsamości miasta, są nauki o zarządzaniu i organizacji. Tożsamość miasta jest tu rozważana jako pojęcie analogiczne do pojęć „tożsamości organizacji” czy „tożsamości przedsiębiorstwa” ${ }^{11}$. Przykładowa definicja tożsamości organizacji brzmi: „suma elementów, które

4 M. Szczepański, Tożsamość regionalna - w kręgu pojęć podstawowych i metodologii badań. Między tożsamościa indywidualna a społeczna - preliminaria, s. 1, www.socjologiarozwoju.us.edu.pl/ documents/25.html (30.06.2012).

5 Ibidem, s. 1.

6 A. Śliz, M. Szczepański, op.cit., s. 278.

7 Yi Fu Tuan, Przestrzeń i miejsce, PIW, Warszawa 1987, s. 75.

8 A. Śliz, M. Szczepański, op.cit., s. 284.

9 Ibidem, s. 278.

10 Ibidem, s. 285.

${ }^{11}$ E. Glińska, Socjologiczna i marketingowa koncepcja tożsamości miasta, w: Obywatelstwo i tożsamość w społeczeństwach zróżnicowanych kulturowo i na pograniczach, t. 1, Wydawnictwo Uniwersytetu w Białymstoku, Białystok 2006, s. 34. 
identyfikują przedsiębiorstwo, wyróżniając je spośród innych firm. [...] Ponadto tożsamość organizacyjna to cele, treść i formy działania, które firma chce utrwalić w otoczeniu" ${ }^{12}$.

Opierając na powyższych definicjach, Ewa Glińska definiuje tożsamość miasta jako „zbiór uwarunkowanych historycznie cech charakterystycznych dla miasta, które wyróżniają je spośród innych i wyrażają się wszelkimi działaniami, jakie są podejmowane w mieście w celu tworzenia jego swoistej osobowości i charakteru". Tożsamość miasta daje miastu wyjątkowość, nadaje mu znaczenia symboliczne, może również pełnić rolę identyfikacyjno-integrującą ${ }^{13}$. Spośród obecnych w literaturze przedmiotu definicji tożsamości miasta autorka wybrała ujęcie E. Glińskiej z uwagi na uwzględnienie w nim historycznych aspektów tożsamości miasta. Są one bardzo istotne dla przedstawionej w opracowaniu analizy, a w innych definicjach pomijane.

\section{Wpływ przemian politycznych, ekonomicznych i społecznych na tożsamość miast we współczesnej Polsce}

Tytuł punktu 2 jest równocześnie tezą, której rozwinięcie jest przedmiotem zamieszczonych tu analiz. Przemiany polityczne, społeczne i ekonomiczne zachodzące w Polsce od 1989 r. nie pozostały bez wpływu na tożsamość polskich miast. W literaturze przedmiotu wśród najważniejszych procesów wpływających na miasto wymienia się transformację ustrojową, globalizację, metropolizację i integrację europejską ${ }^{14} \mathrm{i}$ właśnie te procesy zostały omówione w dalszej części opracowania.

\subsection{Transformacja systemowa}

Na skutek transformacji systemowej doszło do wielu procesów zmieniających wygląd miast polskich. Upadek licznych zakładów przemysłowych przyczynił się do pogorszenia się sytuacji finansowej wielu mieszkańców. W śródmieściach miast pojawiły się opuszczone budynki fabryk. Równocześnie różne obszary poprodukcyjne zaczęły być zastępowane obszarami usługowymi. W latach 90. XX w. bardzo dynamicznie rozwijał się uliczny handel, powstały liczne mniej lub bardziej doraźne

12 A. Zarębska, Tożsamość organizacyjna przedsiębiorstwa. Jak stworzyć konkurencyjna firmę?, Difin, Warszawa 2008, s. 9-10.

${ }^{13}$ E. Glińska, op.cit., s. 33. Por. opracowania takich autorów, jak: A. Łuczak, A. Stanowicka-Traczyk.

14 Opracowania takich autorów, jak: B. Jałowiecki, M.S. Szczepański, J.J. Parysek, M. Malikowski, M. Palak, S. Solecki, J. Słodczyk. 
„bazary”. Innym zjawiskiem, które zmieniło strukturę przestrzenną polskich miast, były procesy suburbanizacyjne ${ }^{15}$. Ponieważ na tereny podmiejskie wyprowadzała się głównie klasa średnia i wyższa, proces doprowadził do zwiększenia społeczno-przestrzennej polaryzacji miasta ${ }^{16}$.

W przemianach tożsamości miasta kluczowe znaczenie miał proces decentralizacji władzy m.in. w wyniku ustawy o samorządzie terytorialnym (gminnym) z 1990 r. ${ }^{17} \mathrm{Na}$ jej mocy zwiększono kompetencje władz lokalnych i umożliwiono swobodne planowanie działań w regionie. Drugą kluczową ustawą była ustawa o wprowadzeniu zasadniczego trójstopniowego podziału terytorialnego państwa z 1998 r., która pozbawiając wiele miast statusu stolicy województwa, przyczyniła się do pogorszenia ich sytuacji gospodarczej ${ }^{18}$. Po upadku PRL i „otwarciu” Polski na wpływy gospodarcze i społeczne z zagranicy coraz wyraźniej jest w Polsce dostrzegany wpływ globalizacji.

\subsection{Globalizacja}

Już w latach 90. XX w. w przestrzeni polskich miast pojawiły się światowe sieci handlu wielkopowierzchniowego ${ }^{19}$. Ta forma handlu zapoczątkowała proces wypierania z rynku drobnych polskich sklepów i handlu ulicznego. Supermarkety, początkowo lokalizowane na obrzeżach miast, $\mathrm{z}$ biegiem czasu zaczęły być otwierane w śródmieściach ${ }^{20}$. W tym samym czasie w Polsce pojawiły się pierwsze „galerie handlowe" 21 . Podobnie jak supermarkety początkowo lokalizowano je na obrzeżach

15 „Suburbanizacja polega na szybkim wzroście liczby ludności osiedli podmiejskich, głównie kosztem ludności obszarów centralnych". Za: M. Malikowski, M. Palak, Zmiany przestrzenne i społeczne w rzeszowskich suburbiach, w: Przemiany przestrzenne w dużych miastach Polski i Europy Srodkowo-Wschodniej, red. M. Malikowski, S. Solecki, Nomos, Kraków 2007, s. 194.

16 S. Solecki, Zmiany funkcjonalno-przestrzenne w Rzeszowie w warunkach metropolizacji, w: Przemiany przestrzenne... , ibidem, s. 180-188, por. J.J. Parysek, B. Jałowiecki uważa procesy suburbanizacji za przejaw metropolizacji.

17 Ustawa z dnia 8 marca 1990 r. o samorządzie terytorialnym, DzU nr 16 poz. 95.

18 Ustawa z dnia 24 lipca 1998 r. o wprowadzeniu zasadniczego trójstopniowego podziału terytorialnego państwa, DzU nr 96 poz. 603.

19 „Pod pojęciem handel wielkopowierzchniowy rozumiane są wielkie obiekty handlowe, popularnie zwane supermarketami, wśród których zwyczajowo zwykło się wyróżniać placówki szczególnie dużych rozmiarów, określając je mianem hipermarketów. W sklepach tych prowadzona jest w trybie samoobsługi sprzedaż artykułów codziennego użytku oraz dóbr trwałych". Za: J. Czarzasty, Stosunki pracy w handlu wielkopowierzchniowym w Polsce, Oficyna Wydawnicza SGH, Warszawa 2010, s. 11-12.

20 J. Kociszewski, Tendencje rozwoju oraz restrukturyzacja miast regionalnych $w$ Polsce, w: Rozwój miast i zarządzanie gospodarka miejska, red. J. Słodczyk, Uniwersytet Opolski, Opole 2004, s. 145.

21 „Nieruchomość handlowa, która została zaplanowana, zbudowana oraz jest zarządzana jako jeden podmiot handlowy, składający się ze sklepów oraz części wspólnych, o minimalnej powierzchni najmu $5000 \mathrm{~m}$ kwadratowych oraz składający się z minimum 10 sklepów”, terminy „galeria handlowa” i „centrum handlowe" używane są w pracy zamiennie. Definicja branżowa stworzona przez International Council 
miast, natomiast w pierwszej dekadzie XXI w. obiekty te pojawiły się w centralnych dzielnicach miasta. Na polskim rynku pojawiły się też sklepy globalnych, popularnych marek odzieżowych, takich jak „H\&M” czy „Zara”, i gastronomicznych, np. „McDonalds” czy „Starbucks”. Początkowo sklepy i punkty gastronomiczne tych marek otwierano na głównych ulicach handlowych miast, z czasem zaczęto je przenosić do galerii handlowych. Ich miejsce na głównych ulicach miasta zajęły oddziały globalnych sieci bankowych czy telefonii komórkowych. Wszystkie te przemiany przyczyniają się do kreacji nowych wzorów konsumpcji, a równocześnie powodują standaryzację przestrzeni miejskiej i grożą utratą specyficznego klimatu poszczególnych miast.

\subsection{Metropolizacja}

Jednym $\mathrm{z}$ bezpośrednich następstw procesów globalizacji jest metropolizacja ${ }^{22}$. Jej skutkami są przekształcenia centralnych dzielnic miast w przestrzeń biurową, budowa strzeżonych osiedli mieszkaniowych oraz nowoczesnych centrów handlowych, którym towarzyszą międzynarodowe sieci hoteli, np. „InterContinental” czy "Sheraton”. Taka zabudowa zmienia charakter i wygląd polskich miast, nadaje im „kosmopolityczny i zamerykanizowany wyraz"23. Ponieważ obiekty te często powstają w bezpośrednim sąsiedztwie socjalistycznych osiedli mieszkaniowych i zdegradowanej przestrzeni publicznej, przyczyniają się do wytworzenia silnych kontrastów w miejskiej przestrzeni oraz ogólnego chaosu w zabudowie ${ }^{24}$. Nowoczesne budynki, o uniwersalnej, podobnej na całym świecie formie są obce polskiej tradycji architektonicznej. $Z$ tego powodu proces metropolizacji przyczynia się do rozmycia tożsamości miasta, do utraty tego, co unikalne i wyjątkowe.

\footnotetext{
of Shopping Centres, globalną organizację działającą w branży centrów handlowych, definicja używana również przez Polską Radę Centrów Handlowych. Za: J. Mikołajczyk, Rozwój centrów handlowych w Polsce, „Zeszyty Naukowe” nr 529, „Ekonomiczne Problemy Usług” nr 30, „Wielkie Miasta, Aglomeracje, Metropolie”, Wydawnictwo Naukowe Usz., Szczecin 2009, s. 138-139.

22 „Metropolizacja [...] proces przejmowania przez niektóre wielkie miasta funkcji kierowniczych $\mathrm{w}$ zarządzaniu gospodarką postindustrialną $\mathrm{w}$ skali ponadnarodowej [...] Cechą metropolii jest przede wszystkim umiędzynarodowienie ich działalności usługowej i znacznie silniejsze związki z innymi metropoliami niż z otaczającym je regionem". B. Jałowiecki, M.S. Szczepański, Miasto i przestrzeń w perspektywie socjologicznej, Wydawnictwo Naukowe Scholar, Warszawa 2006, s. 208.

23 B. Jałowiecki, op.cit., s. 7.

24 Ibidem, s. 7-8.
} 


\subsection{Integracja europejska}

Kolejnym procesem, który wpływa na tożsamość miasta, jest integracja europejska, umożliwiająca korzystanie z programów i funduszy europejskich. Dostęp do środków finansowych pozwala na realizację takich projektów, jak budowa nowych dróg, remonty uczelni wyższych, budowa hal sportowych czy obiektów rekreacyjnych. $\mathrm{W}$ przestrzeni polskich miast zauważalne są również efekty rewitalizacji śródmieść, zabytków czy opuszczonych fabryk. Zrewitalizowana i zadbana przestrzeń miejska zachęca mieszkańców do spędzania na jej terenie czasu wolnego, ożywia miasto. $Z$ drugiej jednak strony Unia Europejska narzuca ścisłe regulacje dotyczące sposobu wykorzystania przyznanych środków finansowych, przez co wpływa na rodzaj realizowanych projektów, a w ten sposób pośrednio kształtuje tożsamość miasta.

\section{Tożsamość miasta Kielce}

Analiza tożsamości miejskiej Kielc została przeprowadzona według następujących kryteriów:

- geneza miasta i uwarunkowania geograficzne,

- rozwój gospodarczy,

- struktura demograficzno-społeczna mieszkańców,

- układ przestrzenny miasta:

- układ architektoniczny,

- przestrzeń publiczna i prywatna,

- infrastruktura kulturalna i symboliczna,

- działalność promocyjna władz miasta,

- status administracyjny miasta,

- obraz miasta w świadomości jego mieszkańców.

Podział ten uwzględnia zarówno uwarunkowania gospodarcze, społeczne, jak i polityczne ${ }^{25}$ oraz wskazuje zależność między perspektywą historyczną i współczesną, dzięki czemu możliwe jest uzyskanie klarownego obrazu tożsamości miasta.

25 Podział autorski. 


\subsection{Geneza miasta i uwarunkowania geograficzne}

Kielce należą do grupy miast, których geneza zapisana jest w ludowych opowieściach. Legenda opowiada o zagubionym na łowach królewiczu, którego ratuje z opresji święty Wojciech, tworząc uzdrawiające źródełko. Wdzięczny opatrzności królewicz na miejscu wydarzeń zakłada osadę z kościołem. Ponieważ na miejscu wydarzeń znalazł wielkie kły, osadę nazywa Kielcami, rzekę, która dodała mu sił, Silnicą, a kościół wznosi pod wezwaniem świętego Wojciecha ${ }^{26}$. Legenda jest najbardziej popularnym wyjaśnieniem etymologii nazwy Kielce - uczą się jej dzieci w szkole, opisuje ją każdy przewodnik po mieście.

Kielce są miastem położonym u stóp Gór Świętokrzyskich, na obszarze tradycyjnie zwanym Kielecczyzną ${ }^{27}$. Jeszcze około 900 r. ziemia kielecka porośnięta była Puszczą Świętokrzyską. Jak podają opracowania historyczne, Kielce powstały jako osada targowa nad rzeką Silnicą. Jej mieszkańcy zajmowali się rolnictwem, obróbką drewna, drobnym rzemiosłem, produkcją węgla drzewnego, pędzeniem smoły. Produkty te wymieniali na miód i zwierzynę zdobywane przez mieszkańców puszczy ${ }^{28}$. Na przełomie X i XI w. książę Władysław Herman przekazał osadę we władanie biskupom krakowskim, co miało istotne skutki dla dalszego rozwoju miasta.

\subsection{Gospodarcze uwarunkowania rozwoju Kielc}

Jak podają źródła historyczne, do XV w. mieszkańcy Kielc zajmowali się przede wszystkim rolnictwem, miasto było również miejscem wymiany między lokalną ludnością. Ważne zmiany nastąpiły na początku XVI w., kiedy powstały pierwsze w Kielcach cechy: szewców, ślusarzy, bednarzy i krawców. Ponadto na mocy królewskiego przywileju zezwolono na organizację cotygodniowego targu, trzech jarmarków w ciągu roku (kolejni królowie zwiększali tę liczbę do czterech, potem pięciu, aż do ośmiu w 1790 r.), wybudowano drogę do Bodzentyna. Rozwój gospodarki rolnej zwiększał zapotrzebowanie na narzędzia do uprawy, a istnienie nadwyżek towarowych pobudzało wymianę. Zapotrzebowanie na środki płatnicze było jednym z powodów rozpoczęcia w XVI i XVII w. intensywnego wydobycia żelaza, ołowiu i miedzi w okolicznych miejscowościach. Budowano kuźnice, rozwijano huty metali

\footnotetext{
26 Oficjalna strona miasta Kielce, http://www.um.kielce.pl/poznajmiasto/legendy/ (03.08.2012).

27 „Określenie ziemia kielecka - Kielecczyzna pojawiło się dopiero w XIX w. [...] Granice Kielecczyzny od wschodu i południa stanowi Wisła, od północy Pilica. Środkową część terenu zajmują Góry Świętokrzyskie". S. Lencewicz, J. Kondracki, Geografia fizyczna Polski, PWN, Warszawa 1959, s. 314.

28 D. Kopertowska, Kielce. Historia i współczesność w nazewnictwie, Wydawnictwo AŚ im. Jana Kochanowskiego, Kielce 2001, s. 13, 22.
} 
i szkła, przetwarzano miedź. Tereny Kielecczyzny posiadały bogate zasoby skał, glin i rud siarki. Rozwijano też tartacznictwo i papiernictwo ${ }^{29}$. W latach 80. XVIII w. z inicjatywy biskupa Kajetana Sołtyka zaczęto wydobywać wapienie na Kadzielni oraz otwarto dwie cegielnie ${ }^{30}$.

Kolejnym ważnym dla rozwoju gospodarczego Kielc wydarzeniem było wybudowanie drogi łączącej Kraków z Warszawą w latach 30. XIX w., a w 1885 r. oddanie do użytku połączenia kolejowego z Dęblina do Dąbrowy Górniczej. W XIX w. powstawały zakłady przemysłowe, takie jak spółdzielnia „Społem”, fabryka marmurów, wapienniki Wietrznia, browar i młyn parowy. Otwierano hotele, budowano kościoły, zaś na początku XX w. rozpoczęto telefonizację miasta ${ }^{31}$.

Po I wojnie światowej Kielce kontynuowały przemysłową tradycję i działało w nich kilka ważnych fabryk: Fabryka Odlewów „Ludwików”, Fabryka „Granat”, Fabryka Mebli „Henryków”, liczne cegielnie oraz elektrownia ${ }^{32}$. W latach 30. XX w. Kielce znalazły się w obrębie Centralnego Okręgu Przemysłowego. Region kielecki $\mathrm{w}$ „COP-ie” pełnił funkcję dostarczyciela surowców, które przetwarzano w regionie sandomierskim ${ }^{33}$. Centralny Okręg Przemysłowy stanowił kontynuację i rozszerzenie tradycji Staropolskiego Okręgu Przemysłowego.

II wojna światowa przyniosła okupację niemiecką, a z kieleckich fabryk Niemcy wywieźli najcenniejsze maszyny produkcyjne. Równocześnie wybrane fabryki produkowały na rzecz okupanta. Fabryki kierowane były przez Niemców, jednak pracujący w nich Polacy potajemnie wynosili produkty oraz przekazywali je ruchowi oporu ${ }^{34}$.

Po wojnie dalej rozwijano przemysł w Kielcach: Fabrykę „Ludwików” przekształcono w Zakłady Wyrobów Metalowych „SHL”, Fabrykę „Granat” w Zakłady Precyzyjne „Iskra”, powstały nowe zakłady: Zakłady Urządzeń Chemicznych i Armatury Przemysłowej „Chemar”, Zakłady Wyrobów Papierniczych, Kieleckie Przedsiębiorstwo Robót Mostowych, „Exbud”, „Chemadin”. To nagromadzenie przemysłu stało się przyczyną rozwoju i rozbudowy miasta.

Po przemianach systemowych w 1989 r. wielowiekowa tradycja hutnictwa, metalurgii, ceramiki oraz kamieniarstwa jest kontynuowana. Z obszaru województwa świętokrzyskiego pochodzi niemal 90\% krajowej produkcji gipsu, a także duża

29 J. Pazdur, Dzieje Kielc do 1863 roku, Ossolineum, Wrocław 1971, s. 60.

30 Ibidem, s. 191.

${ }^{31}$ Strona Urzędu Miasta Kielc, http://www.um.kielce.pl/poznajmiasto/historia/historia3/ (25.06.2012).

32 Oficjalna strona miasta Kielce, http://www.um.kielce.pl/poznajmiasto/historia/historia3/ (07.08.2012).

33 A. Gawryszewski, Ludność Polski w XX wieku, PAN, Instytut Geografii i Przestrzennego Zagospodarowania im. Stanisława Leszczyckiego, Warszawa 2005, s. 34.

34 Z. Guldon, A. Massalski, Historia Kielc do roku 1945, Kieleckie Centrum Kultury, Kielce 2000, s. $352-380$. 
część produkcji cementu, wapna i kruszywa budowlanego ${ }^{35}$. Również specjalizacja działających przedsiębiorstw wskazuje na ciągłość historyczną - w północnej części Kielecczyzny działają firmy związane z przemysłem metalowym, maszynowym, z produkcją materiałów budowlanych, szkła, opakowań z papieru i tektury ${ }^{36}$. W Kielcach powstało dużo firm budowlanych, takich jak „Cersanit”, „Mitex” czy „Echo Inwestment”. Jednakże mimo wyraźnych tradycji industrialnych miasta i regionu, obecności dawnych kamieniołomów w centrum miasta, licznych ruin pieców hutniczych w okolicy, a także dużej liczby przedsiębiorstw budowlanych miasto nie ma wizerunku miasta industrialnego. Wizerunek taki jest niemodny i budzi negatywne skojarzenia $\mathrm{z}$ miejscem nieprzyjaznym, zanieczyszczonym i niebezpiecznym, a władze miasta promują Kielce jako nowoczesną stolicę województwa, centrum turystyczne i biznesowe.

Za „wizytówkę regionu” uważa się założone w 1992 r. „Targi Kielce”. Ułatwiają one kadrze technicznej dostęp do najnowszych rozwiązań konstrukcyjnych i technologicznych ${ }^{37}$. Ich organizacja pociąga za sobą konieczność rozwoju infrastruktury noclegowej, restauracyjnej i rozrywkowej, generuje więc wiele miejsc pracy. Co więcej, przyciągając przedsiębiorców zarówno z Polski, jak i z zagranicy, wyraźnie zaznacza pozycję Kielc na mapie biznesowej kraju, promuje je i przynosi prestiż. Aby zapewnić w województwie świętokrzyskim rozwój gospodarki opartej na wiedzy oraz innowacji, powołano takie instytucje, jak Świętokrzyska Rada Innowacji (ŚRI), Świętokrzyskie Centrum Innowacji i Transferu Technologii Sp. z o.o. (ŚCIiTT), a także Kielecki Park Technologiczny ${ }^{38}$.

\subsection{Struktura demograficzno-społeczna mieszkańców}

Według opracowań historycznych liczba mieszkańców Kielc rosła powoli, co miało wpływ na tempo rozwoju gospodarczego miasta. W XIV w. Kielce liczyły zaledwie 48 pięcioosobowych rodzin i nie miały zasobów siły roboczej, aby rozwijać handel i rzemiosło. Miasto utrzymywało się z upraw rolnych ${ }^{39}$. Okres szybkiego rozwoju demograficznego Kielc zaczął się w XIX w. Miasto zostało wtedy stolicą

35 E. Szot-Radziszewska, Development of modern technologies in the area of the old polish industrial region. Tradition for modernity, w: Scientific basis of modern technologies: experience and prospects, red. Y.I. Shalapko, L.A. Dobrzanski, Department of Principles of Engineering Mechanics of Khmelnitsky National University, Jaremche 2011, s. 20-39.

36 Ibidem, s. 20-39.

37 Strona internetowa Urzędu Miasta Kielce, http://www.um.kielce.pl/gospodarka/targi_kielce/ (27.06.2012).

38 Strona internetowa Kieleckiego Parku Technologicznego, http://www.technopark.kielce.pl/ (20.08.2012).

39 J. Pazdur, op.cit., s. 40-42. 
województwa krakowskiego, zlokalizowano w nim ważne instytucje gospodarcze oraz uruchomiono połączenie kolejowe. Te wydarzenia zachęcały ludzi do osiedlania się w Kielcach. Pod koniec XIX w. w mieście zamieszkiwało już prawie 12 tys. osób $^{40}$, a w przededniu II wojny światowej już 71 tys. ${ }^{41}$ Szczegółowe dane na temat liczby ludności w Kielcach w XIX i XX w. zawiera tabela 1.

Tabela 1. Ludność w Kielcach w XIX i XX w.

\begin{tabular}{|c|c|}
\hline Rok & Ludność \\
\hline 1883 & 11900 \\
\hline 1902 & 14300 \\
\hline 1921 & 41300 \\
\hline 1931 & 58700 \\
\hline 1938 & 67000 \\
\hline 1939 & 71500 \\
\hline 1940 & 80600 \\
\hline 1943 & 57000 \\
\hline 1944 & 52100 \\
\hline 1945 & 53650 \\
\hline
\end{tabular}

Źródło: opracowanie na podstawie: Z. Guldon, A. Massalski, Historia Kielc do 1945 roku, Kieleckie Centrum Kultury, Kielce 2000, s. 329, 354.

Cechą charakterystyczną wyróżniającą Kielce spośród innych miast polskich był brak mieszczan żydowskiego pochodzenia aż do $1862 \mathrm{r}$. Tak długo, jak Kielce należały do biskupów krakowskich, w mieście panował zakaz osiedlania się Żydów. Prawo zwyczajowe było również utrzymywane po przejściu Kielc na własność królewską. Duży społeczny opór przeciw zniesieniu tego zakazu można uzasadnić ochroną interesów gospodarczych kieleckich rzemieślników i obawą przed groźną konkurencją. W 1862 r. weszła w życie ustawa dająca prawo osiedlania się każdemu, niezależnie od narodowości, w dowolnym miejscu całego Królestwa ${ }^{42}$. Od tej pory liczba ludności żydowskiej w Kielcach dynamicznie rosła, stanowiąc w przededniu II wojny światowej $29 \%$ społeczności kieleckiej ${ }^{43}$. II wojna światowa i towarzysząca jej eksterminacja Żydów w znacznym stopniu zmieniła strukturę ludności, prowadząc do praktycznego zniknięcia Żydów z Kielc.

40 Z. Guldon, A. Massalski, op.cit., s. 219.

${ }^{41}$ Ibidem, s. 354.

42 J. Pazdur, Dzieje Kielc do 1863... , op.cit., s. 214-216.

43 Z. Guldon, A. Massalski, op.cit., s. 354. 
Lata powojenne to okres dynamicznego przyrostu ludności w Kielcach. Liczba mieszkańców gwałtownie rosła od 53 tys. po II wojnie światowej, przez 90 tys. w latach 60., aż do 127 tys. w latach 70. Wzrostowi liczby mieszkańców sprzyjał powojenny wyż demograficzny oraz migracje ze wsi związane z rozwijanym w Kielcach przemysłem. Również rozszerzanie granic administracyjnych w latach 70. znacząco wpłynęło na wzrost liczby mieszkańców. Szczegółowe dane dotyczące ludności w Kielcach obrazuje tabela 2.

Tabela 2. Ludność w Kielcach w latach 1950-1985

\begin{tabular}{|l|r|}
\hline Rok & Ludność \\
\hline 1945 & 53650 \\
\hline 1950 & 61000 \\
\hline 1960 & 90000 \\
\hline 1970 & 127000 \\
\hline 1980 & 185000 \\
\hline 1985 & 203000 \\
\hline
\end{tabular}

Źródło: opracowanie na podstawie: Rocznik Statystyczny Demografii, GUS, Warszawa 1996, s. 22.

W 2000 r. Kielce liczyły 213,5 tys. mieszkańców i był to ostatni rok, w którym odnotowano wzrost liczby ludności. Od 2001 r. liczba kielczan systematycznie spada, w 2011 r. Kielce liczyły 196 tys. mieszkańców. Sytuację tę powoduje proces suburbanizacji ${ }^{4}$, wyjazdy kielczan w celach edukacyjnych i zawodowych, a także ujemny przyrost naturalny ${ }^{45}$.

\subsection{Układ przestrzenny miasta}

Układ przestrzenny miasta tworzą: układ architektoniczny, przestrzeń publiczna i prywatna oraz infrastruktura kulturalna i symboliczna.

\subsubsection{Układ architektoniczny}

Początki Kielc wiążą się z dzisiejszym kościołem św. Wojciecha. To tam w X w. koncentrowało się życie osady. Sytuacja ta zmieniła się dwa wieki później, gdy biskup Gedeon ufundował na Wzgórzu Zamkowym Kolegiatę pod wezwaniem Najświętszej

44 Kielce, ambitne miasto liderów. Strategia rozwoju miasta Kielce na lata 2007-2020, WYG International, Kielce 2006, s. 8.

45 Ibidem, s. 9. 
Marii Panny. Wydarzenie to przyczyniło się również do rozbudowy miasta ${ }^{46}$ oraz rozwoju handlu i lokalnego rzemiosła na potrzeby duchowieństwa i mieszkańców okolicznych wsi, którzy odwiedzali Kielce w niedziele i święta ${ }^{47}$.

Kolejne znaczące przemiany w układzie urbanistycznym Kielc nastąpiły w XVI i XVII w. Przebudowano wtedy drewniany pałac biskupów na murowany, wybudowano kościół św. Trójcy oraz kościół na wzgórzu Karczówka wraz z klasztorem bernardyńskim ${ }^{48}$. Postawiono cztery bramy miejskie, które nie zachowały się do czasów dzisiejszych. Najważniejszą zmianą było jednak wybudowanie murowanego ratusza. Do połowy XVII w. zarysowała się dzisiejsza ulica Sienkiewicza ${ }^{49}$. XVII-wieczna rozbudowa na trwałe ukształtowała architektoniczny obraz śródmieścia Kielc oraz podniosła znaczenie miasta $\mathrm{w}$ regionie i w Polsce.

Na początku XIX w. bardzo wyraźne architektoniczne skutki spowodowało przeniesienie do Kielc stolicy województwa krakowskiego ${ }^{50}$. Ponieważ miasto nie dysponowało odpowiednią liczbą lokali, aby zakwaterować 80 urzędników i ich rodziny, rozpoczęto remonty zaniedbanych budynków oraz przebudowę miasta. Brukowano centrum, prowadzono prace kanalizacyjne. Wydano zarządzenie o obowiązku oddzielenia miejskiej zabudowy mieszkalnej od gospodarczej. Wyznaczono tereny na zsyp śmieci, nakazano czyszczenie rynsztoków, porządkowanie podwórek, poprawianie i bielenie fasad budynków, szklenie okien, utrzymywanie latarni przed bramami, a także burzenie niszczejących budynków ${ }^{51}$. Jednakże z powodu braku pieniędzy plany te zostały zrealizowane jedynie w znikomym stopniu ${ }^{52}$.

Kolejne ważne dla Kielc zmiany nastąpiły w latach 20. XX w., gdy uruchomiono sieć kanalizacyjną i wodociągową. W latach $70 . \mathrm{XX}$ w. na przyłączonych do Kielc terenach wybudowano nowe osiedla mieszkaniowe, które miały rozwiązać problem niedostatecznej liczby mieszkań. Wcześniej miejska zabudowa Kielc w praktyce ograniczała się do kilku ulic znajdujących się pomiędzy kościołem św. Wojciecha, katedrą i rynkiem oraz ulicą Sienkiewicza. Na pozostałym terenie dominowało wiejskie budownictwo, niezagospodarowane łąki i pustkowia.

46 D. Kopertowska, op.cit., s. 24.

47 J. Pazdur, op.cit., s. 39-40.

${ }^{48}$ Kościół funkcjonuje do dzisiaj, w tamtym okresie Karczówka była odrębną osadą, do Kielc włączono ją znacznie później.

49 Ibidem, s. 108. Ulica Sienkiewicza jest dzisiaj najważniejszą i najbardziej prestiżową ulicą handlową Kielc.

50 Strona miasta Kielce, http://www.um.kielce.pl/poznajmiasto/historia/historia2/ (03.08.2012). Stało się tak na skutek utworzenia Wolnego Miasta Krakowa.

${ }^{51}$ J. Pazdur, op.cit., s. 191-200.

52 Ibidem, s. 200. 


\subsubsection{Przestrzeń publiczna i prywatna}

Analiza tożsamości Kielc nie byłaby możliwa bez uwzględnienia najważniejszych dla mieszkańców przestrzeni publicznych, czyli rynku i głównego deptaka - ulicy Sienkiewicza. Wytyczony w XIV w. rynek ${ }^{53}$ do dzisiaj wyznacza centralny punkt miasta. Początkowo rynek był placem, na którym odbywała się wymiana towarów. Od XVIII aż do XX w. otaczające rynek pola uprawne były sukcesywnie zastępowane murowanymi kamienicami mieszczańskimi. Wiążą się z nimi różne legendy, np. opowieść o chciwym karczmarzu i skarbie w piwnicach jednej z nich. O ich przeszłości przypominają też działania prywatnych inwestorów. Przykładowo w jednej z kamienic, należącej kiedyś do biskupa Kajetana Sołtyka, przez 25 lat mieściła się kawiarnia „Sołtyki”. Po zachodniej stronie rynku znajduje się ratusz z 1834 r., w którym obecnie zlokalizowany jest Urząd Miasta Kielce. Do 2008 r. na środku rynku znajdowała się fontanna, a wokół niej kwiaty, drzewa i ruchliwe rondo. Obecnie zaś, po gruntownym remoncie ruch uliczny jest ograniczony, powierzchnia placu pokryta brukiem, stoją na nim ławeczki i czasowe wystawy.

Główna ulica handlowa Kielc - ulica Sienkiewicza jest miejscem nawet ważniejszym dla kielczan niż rynek. Jest ona osią miasta, skupia jego życie towarzyskie i handlowe. Ze względu na konkurencję w postaci pobliskich centrów handlowych rola zakupowa ulicy straciła w dużym stopniu na znaczeniu. Miejsce sklepów, które przeniosły swe lokale do centrów handlowych, zastąpiły filie zagranicznych banków oraz operatorów komórkowych. Działają tu jednak drobne punkty usługowe, takie jak cukiernie i lodziarnie oraz większość kieleckich dyskotek, pubów i restauracji. Co ważne, w latach 2001-2006 deptak został przebudowany. Jego nawierzchnię pokryto granitową kostką, postawiono stylowe latarnie i ławki. Remont znacznie podniósł walory estetyczne i użytkowe ulicy. Postawiono również wiele pomników i rzeźb, np. ławeczkę Jana Karskiego czy rzeźbę przedstawiającą Henryka Sienkiewicza. Zarówno przebudowa rynku, jak i ulicy Sienkiewicza odbyły się przy współudziale środków unijnych ${ }^{54}$.

Pojawienie się w przestrzeni Kielc dwóch dużych centrów handlowo-rozrywkowych przyczyniło się do zmiany wzorów konsumpcji, do wykreowania nowych możliwości spędzania wolnego czasu. W każdej z galerii otworzono wyposażony w kilka sal kinowych „Kinopleks” i „Multipleks”. Obecność tych nowoczesnych przestrzeni przyczyniła się do upadku dwóch dotychczas działających kin - przedwojennego kina „Moskwa” i wybudowanej w latach 70. XX w. „Romantiki”.

53 Ibidem, s. 46-48.

54 Oficjalna strona miasta Kielce, http://www.um.kielce.pl/fundusze_unijne/sienk (09.08.2012). 
Przestrzeń miejska Kielc oferuje wiele miejsc rekreacji na łonie natury. Należy tu wspomnieć o Miejskim Parku im. Stanisława Staszica, który zlokalizowany jest u podnóża Wzgórza Katedralnego, a pierwsze wzmianki o nim pochodzą z 1804 r. Równie ważnym miejscem są spacerowe tereny wzdłuż Silnicy. Unikalnymi obszarami w Kielcach są tereny dawnych kamieniołomów: Biesak-Białogon, Wietrznia, Rezerwat Ślichowice im. Jana Czarnockiego i Kadzielnia, obecnie funkcjonujące jako rezerwaty geologiczne, a także popularne miejsce rodzinnych i szkolnych spacerów. Ich obecność jest świadectwem postindustrialnej przeszłości miasta ${ }^{55}$, a równocześnie dowodem udanej rewitalizacji terenu.

Kolejnym miejscem, które istotnie wpływa na tożsamość Kielc, jest nowoczesny stadion piłki nożnej zwany stadionem „Korony Kielce”. Wybudowano go w latach 30. XX w., ale w latach 2004-2006 dokonano jego gruntownej przebudowy. Dzięki temu w momencie otwarcia w 2006 r. był to najnowocześniejszy stadion w Polsce. Nowoczesny stadion oraz odnosząca sukcesy drużyna piłkarska „Korona Kielce” promują miasto, przyczyniają się do sytuacji, w której o Kielcach się mówi, a w telewizji transmituje mecze z Kielc. Zgodnie z teorią Tima Edensora o budowaniu tożsamości narodowej sport jest jednym z wielu elementów budujących tożsamość społeczeństwa ${ }^{56}$. Sport pozwala społeczeństwu zintegrować się, jest ważnym punktem oparcia dla tożsamości, tym ważniejszym, gdy drużyna ma długie tradycje i historię ściśle związaną z dziejami miasta, tak jak „Korona Kielce”.

\subsubsection{Infrastruktura kulturalna i symboliczna}

Biskupi krakowscy pozostawili po sobie w Kielcach dwa ważne budynki: Pałac Biskupów Krakowskich oraz Katedrę Wniebowzięcia Najświętszej Marii Panny. Są to najlepiej rozpoznawane przez kielczan zabytki. Ponieważ Pałac Biskupów Krakowskich długo był jedynym, oprócz ratusza, murowanym budynkiem, po przejściu Kielc na własność królewską był on siedzibą wielu instytucji, np. Szkoły Akademiczno-Górniczej, Głównej Dyrekcji Górniczej czy obecnie Muzeum Narodowego. Równie cennymi zabytkami są liczne kościoły, niektóre z XVI i XVII w.

O kulturalny rozwój miasta dbają liczne muzea: Muzeum Narodowe, Muzeum Lat Szkolnych Stefana Żeromskiego ${ }^{57}$. Urodzony pod Kielcami Stefan Żeromski jest patronem wielu instytucji kulturalnych w Kielcach, np. teatru, a Syzyfowe prace, opisujące proces rusyfikacji w kieleckim gimnazjum męskim, są jednym z ważniejszych utworów o społeczności kieleckiej i jej patriotycznych postawach.

55 Oficjalna strona miasta Kielce, http://www.um.kielce.pl/turystyka/rezerwaty_przyrody/ (03.08.2012).

56 T. Edensor, Tożsamość narodowa, kultura popularna i życie codzienne, Wydawnictwo UJ, Kraków 2004, s. 95-135.

57 Oficjalna strona miasta Kielce, http://www.um.kielce.pl/kultura/muzea/ (07.08.2012). 
Szczególną rolę dla tożsamości Kielc odgrywa Muzeum Historii Kielc. Ukazano w nim historię miasta, a ekspozycję można też oglądać w internecie w trakcie „wirtualnego spaceru”. Znaczącym miejscem dla kieleckiej społeczności jest Muzeum Wsi Kieleckiej. W zabytkowym Dworku Laszczyków organizowane są wystawy przypominające o tradycji i zwyczajach zarówno w regionie kieleckim, jak i w całej Polsce. Pod Kielcami, we wsi Tokarnia znajduje się skansen, obrazowo ukazujący tradycję i folklorystykę regionu. W skansenie znajdują się przeniesione z okolicznych wsi domy, wyposażone zgodnie z realiami okresu pochodzenia. W skansenie organizowane są regularnie takie wydarzenia, jak „Święto chleba” czy „Wytopki ołowiu”.58.

Ważną rolę kulturalną pełni Kieleckie Centrum Kultury ${ }^{59}$, w którym odbywają się przedstawienia i koncerty przyjezdnych grup artystów. W Kielcach ma swą siedzibę również Filharmonia Świętokrzyska im. Oskara Kolberga. W 2012 r. zakończono jej gruntowną przebudowę i filharmonia została oddana do użytku pod nazwą Międzynarodowe Centrum Kultur ${ }^{60}$. O rozwój kieleckiej młodzieży i dzieci dba Wojewódzki Dom Kultury im. Józefa Piłsudskiego. Od wielu lat działają tu zespoły taneczne „Małe Kielczanki”, „Kielce” czy „Trzpioty”, zespoły wokalne i teatralne ${ }^{61}$. Wszystkie wymienione placówki kulturalne znajdują się w ścisłym centrum Kielc, dzięki czemu tworzą zwartą, łatwo dostępną dla zwiedzających infrastrukturę.

Kielce są ważnym ośrodkiem akademickim $\mathrm{w}$ regionie. Początki kieleckich uczelni sięgają początku XVIII w., kiedy rozpoczęło działalność Wyższe Seminarium Duchowne. Kolejna uczelnia powstała w XIX w., gdy Stanisław Staszic postanowił tutaj założyć pierwszą techniczną szkołę wyższą w Polsce, Szkołę Akademiczno-Górniczą ${ }^{62}$. O tej lokalizacji zadecydował pogląd, że instytucje techniczne powinny znajdować się $\mathrm{w}$ pobliżu zakładów produkcyjnych, aby móc szybko reagować na zaistniałe potrzeby oraz wpływać na ich rozwój. Za kontynuację myśli Staszicowskiej można uznać otwarcie latach 70. XX w. Politechniki Świętokrzyskiej. Jej misją jest edukowanie inżynierów, tak potrzebnych w regionie przemysłowo-budowlanym. Oprócz tych uczelni działa w Kielcach założony w 1969 r. Uniwersytet Jana Kochanowskiego ${ }^{63}$ oraz jedenaście wyższych uczelni prywatnych.

58 Strona Muzeum Wsi Kieleckiej, http://mwk.com.pl/pl/ (24.08.2012).

59 Oficjalna strona miasta Kielce, http://www.um.kielce.pl/kultura/centra_kultury/ (07.08.2012).

60 Strona internetowa kieleckiej filharmonii, http://filharmonia.kielce.com.pl/nowa_filharmonia. html (07.08.2012).

${ }^{61}$ Strona internetowa Wojewódzkiego Domu Kultury, http://www.wdk-kielce.pl/ (03.08.2012).

62 Strona Urzędu Miasta Kielc, http://www.um.kielce.pl/poznajmiasto/historia/historia3/ (25.06.2012).

63 W 1969 r. powstała Wyższa Szkoła Nauczycielska (z przekształcenia Studium Nauczycielskiego przeniesionego z Radomia), przekształcona w 1973 r. w Wyższą Szkołę Pedagogiczną, w 2000 r. w Akademię Świętokrzyską. W 2008 r. przemianowano Akademię na Uniwersytet Humanistyczno-Przyrodniczy, od 2011 r. szkoła funkcjonuje jako Uniwersytet Jana Kochanowskiego. 


\subsection{Działalność promocyjna władz miasta}

Dla tożsamości miasta ważna jest obecność symboli oraz działania promocyjno-integrujące władz miasta. Zgodnie z teorią Erica Hobsbawma kreowanie od podstaw symboli wspólnoty oraz organizowanie cyklicznych wydarzeń można nazwać „wynajdywaniem tradycji”. Eric Hobsbawm przeciwstawia ją „tradycji rzeczywistej”, czyli tej, która w życiu społecznym obecna jest od pokoleń. Jednym z zadań tradycji jest wzmacnianie poczucia przynależności do grupy oraz symbolizowanie jej wewnętrznej jedności ${ }^{64}$. W przypadku Kielc tradycją rzeczywistą jest powszechnie rozpoznawany herb miasta. Herb został nadany Kielcom w 1496 r. przez kardynała Fryderyka Jagiellończyka. Przedstawia złotą koronę symbolizującą władzę oraz litery CK będące skrótem od łacińskiego Civitas Kielcensis, co znaczy obywatele Kielc. Motyw korony jest wykorzystywany w różnych współczesnych inicjatywach, które korzystając z jego popularności, czerpią zyski, choć z drugiej strony popularyzują go i przypominają kielczanom o ich tożsamości. Najlepszym przykładem popularyzacji symbolu jest lokalna drużyna piłkarska „Korona Kielce”.

W Kielcach można również mówić o tworzeniu nowych tradycji. Należą do nich wykreowane kilkanaście lat temu, z inicjatywy władz miasta, nawiązujący do ludowych utworów hejnał i logo Kielc. Innym przykładem wynajdowania tradycji jest organizowanie od kilkunastu lat Święta Kielc ${ }^{65} \mathrm{i}$ „Sylwestra pod gwiazdami”.

\subsection{Status administracyjny miasta}

Od przełomu X i XI w., czyli właściwie od momentu powstania, Kielce były siedzibą biskupów krakowskich. Dawało im to silną pozycję w regionie, wyróżniało spośród innych osad Kielecczyzny, dynamizowało rozwój. Od 1260 r. Kielce występowały jako miasto lokowane na prawie polskim, a w XIV w. zostały lokowane ponownie, tym razem na prawie magdeburskim ${ }^{66}$. Znaczenie Kielc istotnie wzrosło w XVI i XVII w. pod wpływem rozwoju górnictwa. Województwo, wówczas sandomierskie, zaliczono do grupy najlepiej uprzemysłowionych w Polsce, a do Kielc przeniesiono miejsce obrad sejmików szlacheckich ziemi sandomierskiej. Istotnym wydarzeniem dla dalszych dziejów miasta była ustawa Sejmu Czteroletniego, na mocy której dobra

64 E. Hobsbawn, T. Ranger, Tradycja wynaleziona, Wydawnictwo UJ, Kraków 2008, s. 9-22.

65 Oficjalna strona miasta Kielce, http://www.um.kielce.pl/miejskie_imprezy/swieto_kielc/ (07.08.2012). Nazwanie święta „Magiczny Weekend” nawiązuje do kampanii promocyjnej województwa. Hasło kampanii brzmiało „Świętokrzyskie czaruje. Poleć na weekend”. Kampania nawiązywała do legend o świętokrzyskich czarownicach, zachęcała do zobaczenia czarujących miejsc w województwie.

66 J. Pazdur, op.cit., s. 40-42. 
biskupie, w tym miasto Kielce, stały się własnością królewską. Skutkiem tej ustawy był $\mathrm{m}$.in. przywilej wybierania deputowanych do sejmu ${ }^{67}$.

W wyniku trzeciego rozbioru Polski w 1795 r. Kielce weszły w obręb zaboru austriackiego, a miasto zostało stolicą powiatu. W 1809 r. Kielce zostały włączone do Księstwa Warszawskiego i dalej pełniły funkcję stolicy regionu.

Po I wojnie światowej Kielce ustanowiono stolicą województwa kieleckiego, a w ich obręb włączono okoliczne miejscowości: Pakosz, Szydłówek, Barwinek, Baranówek, Karczówkę i Czarnów ${ }^{68}$. Granice województwa zmieniały się w latach 1938, 1945, 1950, 1975. W 1998 r. w wyniku reformy administracyjnej województwo kieleckie zostało zlikwidowane i zastąpione większym obszarowo województwem świętokrzyskim ze stolicą w Kielcach ${ }^{69}$. Pierwotny projekt ustawy zakładał włączenie Kielc do województwa Małopolskiego ze stolicą w Krakowie, jednakże protesty społeczne oraz weto prezydenta Aleksandra Kwaśniewskiego przyczyniły się do zmiany tej decyzji.

\subsection{Obraz Kielc w świadomości mieszkańców}

W ramach projektu „Mój Samorząd” na przełomie lat 2009 i 2010 przeprowadzono badania, które zrealizowała firma badawcza PBS DGA oraz Sieć Wspierania Organizacji Pozarządowych „SPLOT”. Projekt miał postać badań ilościowych przeprowadzonych na próbie 501 mieszkańców Kielc oraz badań jakościowych $\mathrm{w}$ postaci dziesięciu indywidualnych wywiadów pogłębionych przeprowadzonych z wybranymi ekspertami.

Z badań wynika, że niemal 85\% rozmówców uważa Kielce za „dobre miasto do życia”. 49\% badanych zauważyło również znaczącą poprawę jakości życia w mieście w latach 2006-200970. Wskazywano na poprawę estetyki miasta oraz jakości edukacji. W tym samym czasie $48 \%$ osób wymieniło rynek pracy jako ten, na którym doszło do pogorszenia sytuacji. Badani wskazywali też na niski poziom nauczania na kieleckich uczelniach wyższych, na hermetyczność środowiska naukowego, brak kontaktów uczelni z biznesem. Za wyjątek uznano tu Politechnikę Świętokrzyską. Mówiono o niesprzyjających warunkach do rozwoju przedsiębiorczości, takich jak brak odpowiedniej infrastruktury, brak systemu ulg i zachęt. Kielczanie negatywnie oceniali działalność promocyjną władz miasta. Uważali, że organizowanym

67 Ibidem, s. 60.

${ }^{68}$ J. Główka, A. Oborny, M. Pieniążek-Samek, Kielce. Historia, kultura, sztuka, Wydawnictwo Jedność, Kielce 2003, s. 199.

69 A. Gawryszewski, op.cit., s. 41-61.

70 Mój Samorząd. Raport ilościowo-jakościowy z badania na temat jakości życia w Kielcach, s. 5-8. 
wydarzeniom brakuje medialnego nagłośnienia, a główne atuty Kielecczyzny, takie jak położenie w bezpośrednim sąsiedztwie Gór Świętokrzyskich oraz dobrze rozwinięta infrastruktura rekreacyjna, pozostają niedoceniane i niewykorzystane ${ }^{71}$.

Badani podkreślali, że dzięki optymalnej wielkości Kielce łączą zalety średnich i małych miast. Jako atrybuty średniego miasta wymieniano możliwość „utrzymania się", dość szeroką ofertę edukacyjną i kulturalną. Podkreślano zaletę w postaci małych odległości w mieście, umożliwiających sprawną komunikację. Jako wyróżniki małego miasta wymieniano umiarkowane tempo życia oraz brak anonimowości, które dają mieszkańcom poczucie bezpieczeństwa i przynależności ${ }^{72}$.

89\% badanych kielczan deklarowało zainteresowanie wydarzeniami w mieście, 88\% badanych czuło się współodpowiedzialnymi za swoje miejsce zamieszkania oraz wyraziło chęć współdecydowania w ważnych dla miasta sprawach. W tym samym czasie $60 \%$ badanych narzekało na brak konsultacji społecznych podczas podejmowania przez władzę lokalną ważnych decyzji dotyczących miasta. Mimo tych deklaracji w badaniu jakościowym eksperci twierdzili, że zaangażowanie kielczan na rzecz rozwoju miasta jest niewielkie ${ }^{73}$.

\section{Podsumowanie}

W pierwszej części tekstu zdefiniowano tożsamość miasta jako zbiór uwarunkowanych historycznie cech, które wyróżniają miasto spośród innych miast, sprawiają, że jest ono wyjątkowe i unikalne. Przeanalizowano historię Kielc od momentu jego założenia aż do czasów współczesnych, podkreślając elementy, które nadają Kielcom niepowtarzalną tożsamość.

Pierwszą unikalną cechą Kielc była przynależność do biskupów krakowskich. Skutkiem kościelnego charakteru miasta był zakaz osiedlania się Żydów na jego terenie oraz wybudowanie w XII w. drewnianego Pałacu Biskupów Krakowskich, który na przełomie XVI i XVII w. zamieniono na murowany. Obecność dużego, murowanego obiektu była często argumentem decydującym podczas wyboru lokalizacji dla ważnych przedsięwzięć. Dzięki obecności tego pałacu w Kielcach zlokalizowano Szkołę Akademiczno-Górniczą oraz Główną Dyrekcję Górniczą.

Drugą niepowtarzalną cechą Kielc jest ich położenie w Górach Świętokrzyskich. Bogactwo wierzeń i legend związanych z tym regionem do dzisiaj jest żywe,

${ }^{71}$ Ibidem, s. 10.

72 Ibidem, s. 11.

${ }^{73}$ Ibidem, s. 12-22. 
a motyw świętokrzyskiej czarownicy stał się tematem przewodnim kampanii promocyjnej miasta i regionu. O Górach Świętokrzyskich pisał Stefan Żeromski, góry te stały się też miejscem wielu walk w trakcie powstań niepodległościowych, I czy II wojny światowej. Góry Świętokrzyskie okazały się być również zasobne w surowce naturalne, co znacznie przyspieszyło rozwój gospodarczy Kielc, zachęciło ludność do osiedlania się w tym mieście, było też powodem uczynienia Kielc stolicą województwa na przełomie XVI i XVII w.

Status administracyjny Kielc jest kolejnym ważnym wyróżnikiem. Choć w regionie były miejscowości o podobnym stopniu rozwoju gospodarczo-społecznego, a czasem nawet wyższym (np. Sandomierz), to Kielce były wielokrotnie wybierane na stolicę województwa. Również w 1998 r., mimo głosów sprzeciwu, Kielce utrzymały status miasta wojewódzkiego.

Następnym czynnikiem kształtującym tożsamość Kielc jest ich układ przestrzenny. Wszystkie ważne $\mathrm{w}$ Kielcach przestrzenie publiczne są silnie związane z dziejami miasta. Górująca nad miastem katedra wraz z Pałacem Biskupów Krakowskich są najlepiej rozpoznawalnymi zabytkami w mieście. Rynek i ulica Sienkiewicza, mimo konkurencji nowoczesnych galerii handlowych, pozostają osią życia towarzyskiego Kielc. Kielczanie cenią również miejskie przestrzenie rekreacji, a w szczególności Kadzielnię, Park im. Stanisława Staszica oraz tereny wzdłuż Silnicy. W przypominaniu kielczanom o ich tożsamości szczególną rolę pełni drużyna piłkarska „Korona Kielce” oraz nowoczesny stadion, które dla wielu są powodem do dumy. Muzea przedstawiają dziedzictwo kulturowe regionu, a liczne pomniki w przestrzeni miasta przypominają o dawnych wydarzeniach i ludziach. Zróżnicowanie przestrzeni publicznych Kielc sprzyja dbaniu o tożsamość miasta.

Ostatnim czynnikiem kształtującym wyrazistą tożsamość miasta są ludzie, którzy dane miasto zamieszkują. Z przeprowadzonych badań wynika, że kielczanie lubią swoje miasto, są zadowoleni z zachodzących w nim zmian oraz dbają o jego rozwój.

Odpowiadając na pytanie, jaki wpływ na tożsamość Kielc mają współczesne przemiany polityczne, gospodarcze i społeczne, trzeba zwrócić uwagę na każdy z tych procesów osobno. Kielce uniknęły negatywnych skutków transformacji gospodarczej, jakie spotkały wiele miast. Bardzo wyraźnie natomiast zarysowuje się proces suburbanizacji, liczba mieszkańców Kielc od dziesięciu lat regularnie spada.

Kielce nie poddały się unifikacji, jaką niesie ze sobą globalizacja. Obecne superi hipermarkety znajdują się w większości na obrzeżach miasta i dzięki temu nie zdominowały jego przestrzeni. Globalizacja zmieniła wygląd ulicy Sienkiewicza. Większość obecnych dotychczas na deptaku sklepów odzieżowych przeniosła swe lokale do centrów handlowych. W ich miejscu pojawiły się liczne oddziały banków i telefonii komórkowych. Mimo to ulica Sienkiewicza jest miejscem skupiającym życie 
miasta. Globalne firmy sieciowe, takie jak „Coffee Heaven”, „Starbucs” czy „Subway”, na razie nie mają swych lokali w Kielcach. Stało się tak prawdopodobnie dlatego, że rynek Kielc jest dla nich za mały i nieatrakcyjny. Paradoksalnie fakt ten jest szansą dla lokalnych firm usługowych, jest również szansą zachowania klimatu miejsca. Od wielu lat prężnie rozwija się lokalna piekarnia „Pod Telegrafem”, która regularnie rozszerza sieć swoich lokali i zakres świadczonych usług.

Wpływ metropolizacji na Kielce jest niewielki. Kielce nie są zaliczane do grona polskich metropolii. W mieście nie buduje się dzielnic biurowych, nieliczne biurowce są rozprzestrzenione po całym mieście. Również budowa osiedli grodzonych nie jest masową tendencją. W krajobrazie miasta raczej dominują wieżowce $\mathrm{z}$ lat 70. i 80. ubiegłego wieku, niektóre zostały odnowione, większość jednak pozostaje zaniedbana.

Wpływ integracji europejskiej przejawia się przede wszystkim w postaci rewitalizacji miasta i rozbudowy jego infrastruktury. Oprócz wspomnianej w pracy rewitalizacji rynku i ulicy Sienkiewicza przebudowano wiele dróg, otworzono „kładki dla pieszych". Ze środków unijnych rozbudowano i odnowiono budynki Politechniki Świętokrzyskiej, wybudowano nowoczesną halę sportową dla studentów. Zmodernizowano również amfiteatr na Kadzielni i stadion „Korony Kielce”.

Podsumowując, należy stwierdzić, że historia i warunki, w jakich ukształtowały się Kielce, sprzyjały wytworzeniu wyrazistej tożsamości miasta. Kielce korzystają z pozytywnych aspektów współczesnych przemian. Miasto modernizuje swą infrastrukturę i wygląd. Docierają do niego efekty działalności transnarodowych korporacji w postaci wielkopowierzchniowych sklepów, zagranicznych marek odzieżowych i globalnych sieci bankowych. Obiekty te nie dominują jednak w przestrzeni miasta i nie zmieniają w sposób diametralny jego charakteru. Kielce są średniej wielkości miastem i w niewielkim stopniu podlegają procesom metropolizacji. Nie są ważnym ośrodkiem biznesu, nie przyciągają więc elit metropolitarnych, które tworzyłyby „przestrzeń przepływów” i przyczyniały się do powstania zunifikowanej tkanki miejskiej. Współczesne procesy globalne nie są więc zagrożeniem dla tożsamości Kielc. Znacznie poważniejszym problemem może stać się wysokie, sięgające 14,9\% bezrobocie w Kielcach ${ }^{74}$. Jeśli sytuacja nie ulegnie poprawie, istnieje wysokie prawdopodobieństwo, że ludzie młodzi i wykształceni będą wyjeżdżać z miasta, co wpłynie negatywnie na jego rozwój gospodarczy i społeczny, a w dalszej perspektywie również na tożsamość.

\footnotetext{
${ }^{74}$ Strona internetowa Wojewódzkiego Urzędu Pracy, http://www.wup.kielce.pl/ (20.10.2012).
} 


\section{Słowa kluczowe:}

tożsamość miasta, Kielce, transformacja systemowa, metropolizacja, uwarunkowania rozwoju miasta, układ przestrzenny, promocja miasta, obraz miasta w oczach mieszkańców

\section{Keywords:}

identity of the city, Kielce, transition, metropolisation, conditions for the development, spatial structure, promotion of the city, the city's image in the opinion of residents

\section{City identity in the context of political, economic and social changes in contemporary Poland: the case of Kielce}

City identity can be defined as a historically distinctive attributes that distinguish that city form all the other cities. Identity is influenced by many factors such as: genesis of a city, economic development, spatial arrangements and the picture of a city in the collective mind of its inhabitants. City identity is not permanent feature. It is influenced by political, social and economic changes. The most important factors that influence city identity are: system transformation, globalization, metropolization and European integration. The combination of all these processes and their influences on the identity of contemporary city, such as Kielce, is the aim of this study.

\section{L'identité de la ville dans le contexte des changements politiques, économiques et sociaux en Pologne - le cas de Kielce}

Le concept d' «identité de la ville» peut être expliqué comme un ensemble des traits historiquement conditionnés, qui distinguent une ville par rapport aux autres villes. Cette identité est façonnée par de nombreux facteurs tels que, entre autres, la genèse de la ville, le développement économique, l'aménagement du territoire et l'image de la ville dans l'esprit de ses habitants. Cependant, l'identité de la ville n'est pas une caractéristique permanente et est influencée par des changements politiques, sociaux et économiques. Parmi les processus les plus importants affectant 
cette identité il y a la transformation systémique, la mondialisation, la métropolisation et l'intégration européenne. La rélation entre ces processus et l'identité de la ville moderne fait l'objet d'une analyse dans cet article. Une exemplification empirique des changements d'identité de la ville sous l'influence des conditions sociales, politiques et économiques est présentée sur l'exemple de Kielce. Cet article fait partie d'un projet scientifique intitulé «Les identités culturelles en Europe - la continuité et le changement» sous la direction d'Elżbieta Firlit, professeur à l'École Centrale de Commerce à Varsovie.

\section{Тождество города в контексте политических, экономических и общественных перемен в современной Польше. Казус города Кельце}

Понятие тождества города можно объяснить как совокупность исторически обусловленных черт выделяющих город на фоне других городов. Тождество определяется рядом факторов как генезис города, уровень экономического развития, его пространственная структура или изображение города в сознании его жителей. Однако, тождество города не постоянное качество и подвергается влиянию политических, общественных и экономических перемен. Среди наиболее важных процессов влияющих на тождество города состоят: системная трансформация, глобализация, метрополизация и Европейская интеграция. Статья включает анализ связи именно этих процессов с тождеством современного города. Эмпирической иллюстрацией перемены тождества города под влиянием более широких общественных, политических и экономических процессов является казус города Кельце. Эта статья является частью научного исследования под названием „Культурные тождество в Европе - непрерывность и изменение”, проведенного проф. Эльжбетой Фирлит. 